Citation: Karim Marini Thome, Vitoria A. Leal Paiva (2020) Sparkling Wine International Market Structure and Competitiveness. Wine Economics and Policy 9(2): 37-47. doi: 10.36253/web-8433

Copyright: $@ 2020$ Karim Marini Thome, Vitoria A. Leal Paiva. This is an open access, peer-reviewed article published by Firenze University Press (http:// www.fupress.com/wep) and distributed under the terms of the Creative Commons Attribution License, which permits unrestricted use, distribution, and reproduction in any medium, provided the original author and source are credited.

Data Availability Statement: All relevant data are within the paper and its Supporting Information files.

Competing Interests: The Author(s) declare(s) no conflict of interest.

\section{Sparkling Wine International Market Structure and Competitiveness}

\author{
Karim Marini Thome*, Vitoria A. Leal Paiva \\ University of Brasilia, UnB, Campus Universitário Darcy Ribeiro, ICC, Asa Norte, 79910- \\ 970, Brasilia, DF, Brasil. Email: thome@unb.br \\ ${ }^{\star}$ Corresponding author
}

\begin{abstract}
This paper aims to analyse the Sparkling Wine international market structure and competitiveness, focusing on the 2004-2018 period. It used the data regarding exports and imports of sparkling wine available in the International Trade Centre's Trade Map database. The method used to examine sparkling wine's international market structure and competitiveness consisted of calculation of: (i) Revealed Comparative Advantage (RCA); (ii) Relative Position in the Market (RPM); (iii) Hirschman-Herfindahl Index (HHI); and (iv) Net Export Index (NEI). The paper analyses the growth of the sparkling wine trade worldwide. It demonstrated that France had the greatest relative position in the market, followed by Italy and Spain. This same sequence was found in the revealed comparative advantage, highlighting the increased Italian export level. A high export market structure concentration was also shown. On the other hand, there was an unconcentrated import market structure, and, according to the NEI, it was possible to identify three groups composed of actors who were stable in terms of: i) exports based on domestic production (France, Italy and Spain); ii) trade, reflecting re-export (Singapore and the Netherlands); iii) imports, with strong domestic consumption (Germany, the United Kingdom, the United States of America, Australia, and Belgium).
\end{abstract}

Keywords: wine competitiveness, market structure, sparkling wine, HHI, revealed comparative advantage.

\section{INTRODUCTION}

Sparkling wine, which is known as a celebratory beverage, and also as a lifestyle symbol, has a strong symbolic function (Velikova et al., 2016). The earliest mentions of sparkling wine production date back to 1531 at the SaintHilaire monastery in the South of France (Stevenson, 2003).

The most famous, prestigious, expensive, and highest ranked sparkling wines come from Champagne (Epstein, 2011; Rokka, 2017). The products of that area carry the denomination of origin, and are named as Champagne. Sekt, cava, crémant, and prosecco are familiar terms used to describe the different sparkling wines from outside the Champagne region, and these are becoming better known in the world. Furthermore, their consumption has been trending upwards due to the strong influence of Western culture, 
reflecting luxury fads (Epstein, 2011), the trend toward indulgence, and to differentiate the chosen wine in order to enhance the experience (Hannin et al., 2010; Mariani, Pomarici and Boatto, 2012).

The wine industry is a multibillion-dollar business engaged in world trade. In 2018, sparkling wine export figures rose to more than US $\$ 7$ billion worldwide (ITC, 2020). France maintains its leadership in sparkling wine exports as a result of its specialisation in winemaking and attention to terroir (Zhao, 2005; Demossier, 2011). However, recent studies reveal changing dynamics in the sparkling wine market, whether due to new entrants (Basso, 2019), new consumers and new consumer behaviour (Castellini and Samoggia, 2018; Velikova et al., 2016; Lerro et al., 2020), or strategies for maintaining established markets (Rossetto and Gastaldello, 2018), resulting in a complex situation described, for example, by Pomarici (2016).

In addition, since the beginning of the 21st century, the sparkling wine trade has been growing and its structure has been undergoing changes due the new competitive market scenario (Mariani et al., 2012). However, just a few studies analyse the international wine market in a sectioned manner in countries (Anderson, 2018; Beluhova-Uzunova and Roychev, 2018; Corsi, Marinelli and Sottini, 2013) or sets of countries (Fleming, Mounter, Grant, Griffith and Villano, 2014; Lombardi, Dal Bianco, Freda, Caracciolo and Cembalo, 2016), and no study deals with international sparkling wines market. Thus, this paper fills that lack of studies by analyse the sparkling wine market regarding its: (1) international competitiveness; and (2) international market structure.

\section{THEORETICAL BACKGROUND AND METHOD}

Competitiveness can be examined in multiple ways. This paper follows Latruffe's (2010) idea, where competitiveness is defined by the capacity to face competition and be successful. Comparison is inherent in this view, which can be between different units (such as different countries) in a specific factor or the same unit (the same country) with its respective factor in a different period of time.

Competitiveness can be determined by three different levels: microeconomic (firm), mesoeconomic (sector) and macroeconomic (nation), as seen in Drescher and Maurer (1999) and Bojnec and Fertö (2009). This paper considers the mesoanalytical level involving sparkling wine.

According to Horn (1985), the mesoanalytical level can be measured with different indicators. Trade theory suggests that the nation's competitiveness should be defined by comparative advantage. The comparative advantage theory reveals that trade flows are a result of the relative cost differences among trading partners, suggesting that countries are competitive in the sectors in which they have greater efficiency (Horn, 1985; Bojnec and Fertö, 2009).

To determine the competitiveness of the international sparkling wine market we used the Revealed Comparative Advantage (RCA) initially developed by Balassa (1965), and later modified by Vollrath (1991) to avoid duplicate registers. This was applied in the wine sector by Anderson (2018), Maté Balogh and Jàmbor (2017), Beluhova-Uzunova and Roycheva (2017), Van Rooyen et al. (2010) and Crescimanno and Galati (2014). The index is sustained by exports, revealing the relation between the nation's exported product to its total export flow, and the world's export performance for the same product, in the same period, as follows:

$\mathrm{RCA}=\left(\frac{x_{i p}^{t} / X_{t p}^{t}}{X_{i m}^{t} / X_{t m}^{t}}\right)$

where:

$\mathrm{RCA}=$ revealed comparative advantage

$X_{i p}^{t}=$ exports of product $i$ from the country in period $t$

$X_{t p}^{t}=$ exports from the country in period $t$

$X_{i m}^{t}=$ exports of product $i$ across the world in period $t$

$X_{t m}^{t}=$ exports across the world in period $t$

The higher the final value is, the higher the nation's revealed comparative advantage, whereas the lower the final value, the higher the disadvantage (Vollrath, 1991; Bojnec and Fertö, 2009; Fleming et al., 2014).

In addition to the RCA, the Relative Position in the Market (RPM) is also used, which determines the nation's position in the international trade of a specific product (Thomé and Soares, 2015). It is revealed by calculating the relationship between the nation's trade balance for a specific product and the total global trade for the same product (Thomé and Soares, 2015; Lafay et al., 1999), as follows:

$\mathrm{RP} M_{i}^{t}=100 x \frac{X_{i}^{t}-M_{i}^{t}}{W_{i}^{t}}$

$\mathrm{RP} M_{i}^{t}=$ relative position in the market

$X_{i}^{t}=$ exports of product $i$ from the country in period $t$

$M_{i}^{t}=$ imports of product $i$ into the country in period $t$

$W_{i}^{t}=$ global trade (exports plus imports) of product $i$ in period $t$

The RPM follows the same pattern as the RCA, which means that the higher the final value is, the greater its market position. 
Beyond the RCA and RPM indexes, the Industrial Organisation is a useful framework to understand how market structure influences performance, as shown by Iwasaki et al. (2008), Mariani, et al. (2012) and Thomé and Soares (2015).

The structure-conduct-performance (SCP) paradigm advocates a direct link between market structure and the degree of competition (Bain, 1951). According to the SCP, greater market concentration allows those holding bigger market shares to exploit market power to obtain greater profits (Bain, 1951; Iwasaki et al., 2008).

As seen in Scherer and Rosss (1990), market concentration is the union of the largest market shares in a given sector, and, according to Correia, Gouveia and Martins (2019), this same consideration is applicable to the international wine business.

A high market concentration occurs when few competitors hold a significant share of it, while a large majority of players operate in the rest of the market. In contrast, low market concentration occurs when there is a large number of competitors in similar conditions (Thomé and Medeiros, 2016).

Market concentration is an important aspect of the market structure. Where companies are located affects their performance by reflecting the country's competitive position (Thomé, Medeiros and Hearn, 2017), thus, market concentration can be seen as a relevant performance indicator (Thomé and Soares, 2015).

As seen in Iwasaki et al. (2008), concentration measures should be based on the international market share of each country. They can be expressed in different ways and need to consider the inequality of international market shares and the number of countries (competitors). According to the U. S. Department of Justice and Federal Trade Commission, Horizontal Merger Guidelines (2010), the value of HHI varies between zero, indicating a monopolistic position, to ten thousand, indicating pure monopoly. Otherwise, an index value lower than 1,500 indicates that the industry or market is unconcentrated; for values between 1,500 and 2,500, the market is moderately concentrated; and for HHI with a value above 2,500 , the market is highly concentrated. Among the possible equations used to express market concentration, Iwasaki et al. (2008) highlighted the Hirschman-Herfindahl Index (HHI):

$\mathrm{HHI}=\sum_{i=1}^{n} S_{i}^{2}$

where:

HHI = Herfindahl-Hirschman Index

$S_{i}^{2}=$ market share squared

$\mathrm{n}=$ total countries in the sector
Furthermore, another helpful index that allows understanding of competitive conduct in international trade is the net export index (NEI). The NEI refers to the product's import/export flow (Banterle and Carresi, 2007; Pascucci, 2018). This index not only helps in the debate on sparkling wine re-exportation emphasised by Pomarici (2016), but also shows the countries that use this strategy and at which level. According to Mariani et al. (2012, p. 33), re-exportation is the act of "exporting from one country wine previously imported", which takes into account the country's trade balance for product $i$, due to the total trade for the same product. Based on Banterle and Carresi (2007) and Thomé and Soares (2015), it is calculated as:

$\mathrm{N} E I_{i}^{t}=\frac{X_{i}^{t}-M_{i}^{t}}{W_{i}^{t}}$

where:

$N E I_{i}^{t}=$ the net export index

$X_{i}^{t}=$ exports of product $i$ from the country in period $t$

$M_{i}^{t}=$ imports of product $i$ into the country in period $t$

$W_{i}^{t}=$ the trade (exports plus imports) of product $i$ of the country in period $t$

The index fluctuates between -1 (when the country only imports the product) to 1 (when the country only exports the product). When its result reaches 0 , the country both exports and imports.

The data for this paper were extracted from the International Trade Centre (ITC) database, from 2004 to 2018 for product 220410: Sparkling wine of fresh grapes. The ITC is a subsidiary organisation of the World Trade Organisation (WTO) and the United Nations (UN), with the purpose to provide trade reports and technical assistance for developing countries (ITC 2020).

\section{RESULTS AND DISCUSSION}

This study identifies the major international players in the sparkling wine sector, verifying and describing their evolution in the annual growth transactions. The identification was measured in thousands of US Dollars, as follows.

\subsection{Importers}

In the results of the ten main importers, according to the data presented in Figure 1, it is possible to see that, although all the countries were affected by the 2009 financial crisis, the total amount of sparkling wine imports increased over the period analysed. 


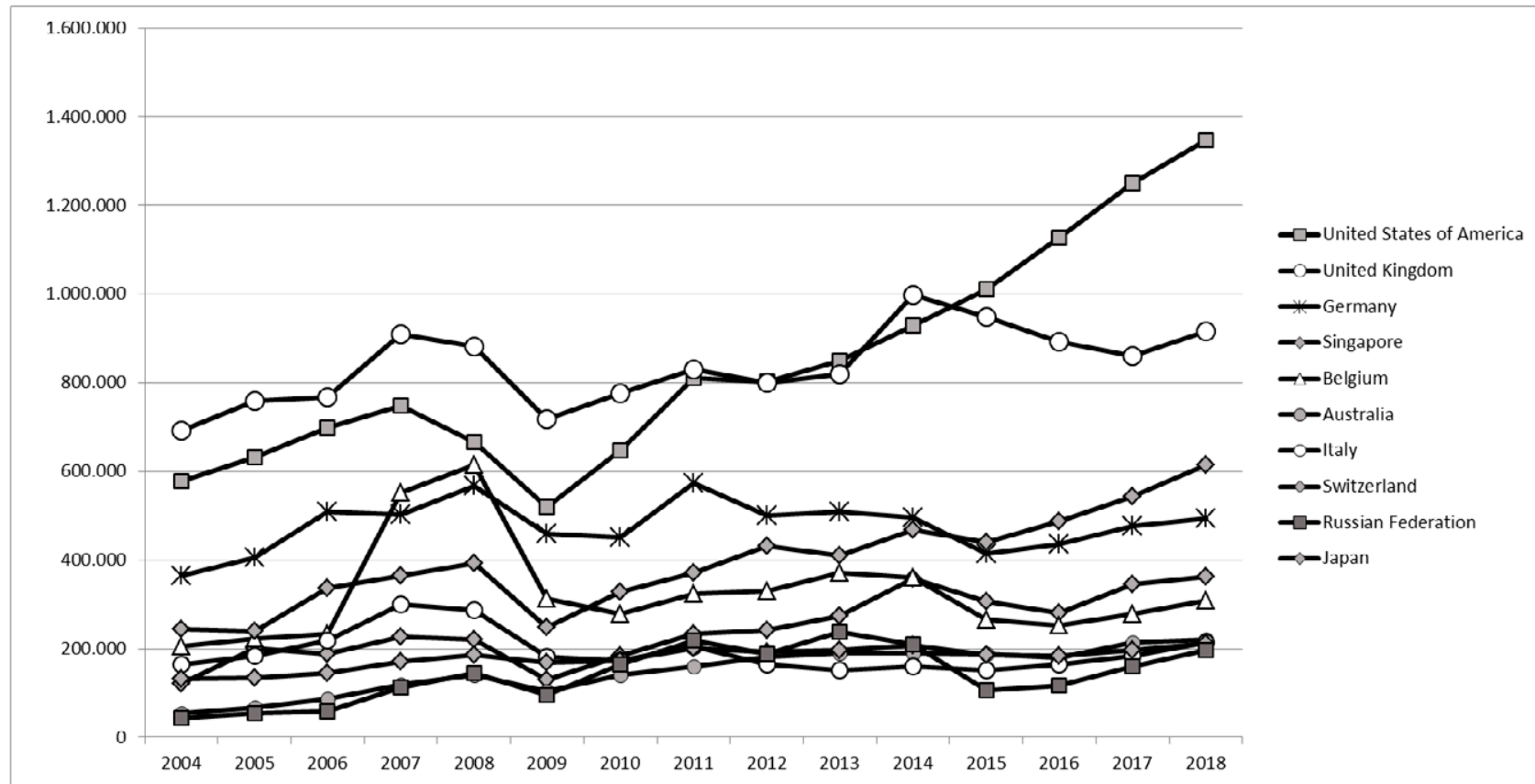

Figure 1. Top 10 importers (US\$) of sparkling wine, 2004-2018. Source: Our own calculations based on ITC data.

The USA is the world's largest importer of sparkling wine, followed by the UK. Prior to 2014, the UK had led, but the two countries changed position, and, ever since, the USA has remained in first place. Its imports have grown continuously, and its annual average growth rate was $8.83 \%$ during the period under analysis, as presented in Table 1.

Like the UK and the USA, albeit presenting smaller values, Germany, Japan, Singapore and Belgium have also changed their positions over the period. It is also noteworthy that Singapore (13.36\%) and Japan (10.14\%) were third and fourth respectively in terms of annual average growth rate.

The Russian Federation, experienced its highest average annual growth (23.06\%), mainly due to increasing imports of Italian sparkling wine, as described by Crescimanno and Galati (2014). This was followed by Australia, which had increased its imports due to a drop in domestic sales of national sparkling wine (see Verdonk et al., 2017), thus presenting an average annual growth of $20.38 \%$.

\subsection{Exporters}

The results show France as the greatest sparkling wine exporter, as seen in Figure 2. Its exports were outstanding when compared to other exporters. Throughout the period analysed, France held the largest portion
Table 1. Annual average growth (US\$) of the Top 10 sparkling wine importers.

\begin{tabular}{lcccc}
\hline & 2004 & 2018 & Difference & $\begin{array}{c}\text { Annual } \\
\text { average } \\
\text { growth (\%) }\end{array}$ \\
\hline USA & 578,649 & $1,348,136$ & 769,487 & 8.83 \\
UK & 691,460 & 916,638 & 225,178 & 2.17 \\
Japan & 244,031 & 615,558 & 371,527 & 10.14 \\
Germany & 364,751 & 493,531 & 128,780 & 2.35 \\
Singapore & 120,879 & 363,299 & 242,420 & 13.36 \\
Belgium & 205,837 & 308,859 & 103,022 & 3.33 \\
Australia & 54,394 & 220,742 & 166,348 & 20.38 \\
Italy & 163,920 & 213,777 & 49,857 & 2.02 \\
Switzerland & 132,138 & 211,441 & 79,303 & 4.00 \\
Russian Federation & 43,907 & 195,843 & 151,936 & 23.06 \\
\hline
\end{tabular}

Source: Our own calculations based on ITC data.

of this market. Such stability can be explained by the fact that French wines attract and fascinate consumers in a way that wines from no other country do (Phillips, 2016), and their management of quality and production, combined with their promotion and distribution techniques, have placed France in the foreign market as a producer of high quality wines (Corsi et al., 2013).

The second and third places were shared by Italy and Spain. For Spain, the data showed stability, while 


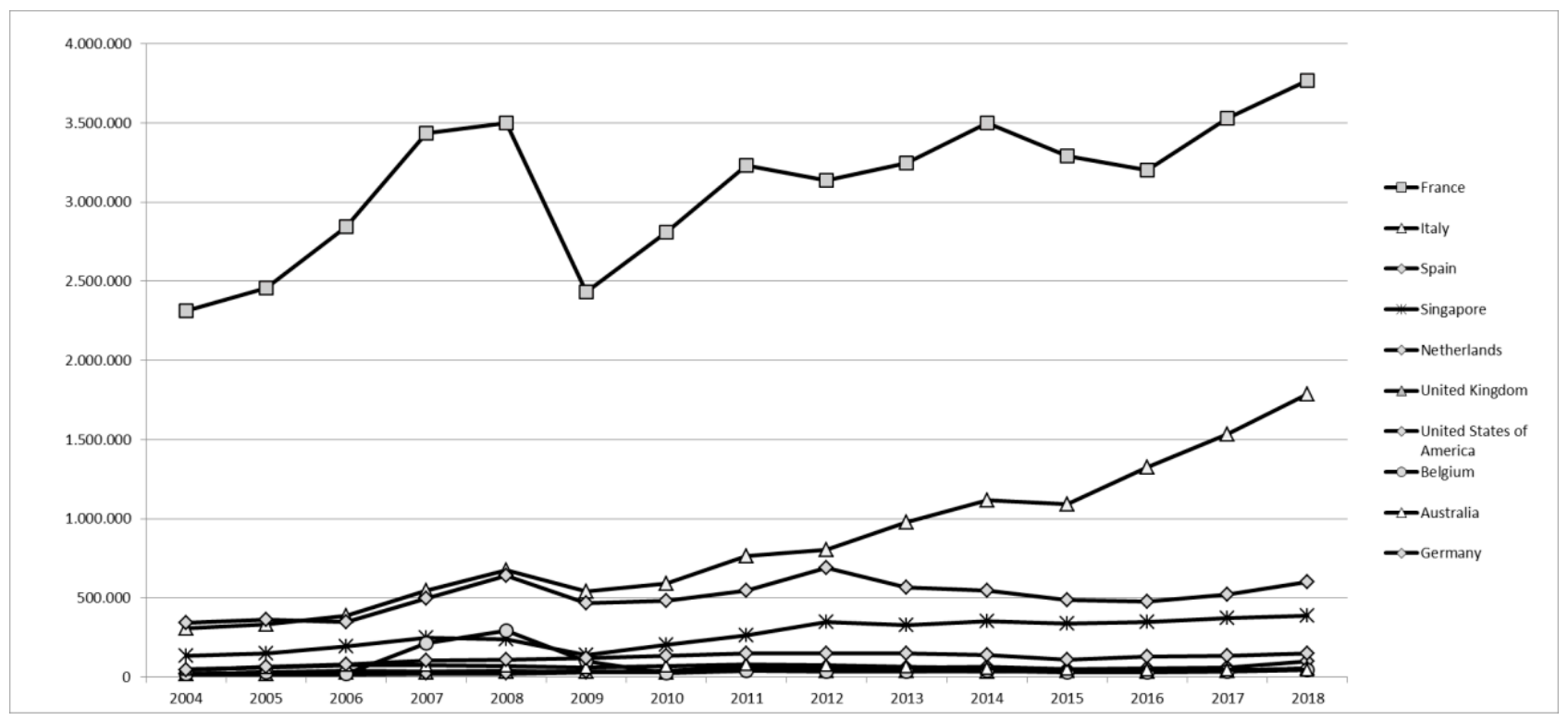

Figure 2. Top 10 exporters (US\$) for sparkling wine, 2004-2018. Source: Our own calculations based on ITC data.

Italian sparkling wine exports presented a constant increase that had begun in 2005, thus remaining as the second biggest exporter.

The 2009 financial crisis affected Italy more mildly than France, causing Italian exports to fall less than the French ones. In 2011, after just 3 years, it can be seen that Italy managed to exceed its 2008 figure, and has since continued to grow steadily. France, despite remaining in first place throughout the entire analysis, only managed to surpass its 2008 exports nine years later, that is, in 2017.

It is important to note that, after the crisis, consumers' purchasing power became limited, making them opt for more affordable sparkling wines (Lero et al., 2019), but they also maintained their ties of tradition and territory (Corsi et al., 2013), which contributed to the growth of Italian and Spanish exports.

As seen in Table 2, among the largest exporters of sparkling wine, Italy enjoyed the highest average annual growth $(32 \%)$ during the timeline, which was explained by Crescimanno and Galati (2014), revealing that the country knew how to take advantage of the opportunities that had arisen with the change in the international wine market. Thus, it expanded exports due to its capacity to meet a diversified demand that required high-quality wines.

Among the four largest exporters of sparkling wine, Singapore showed growth in its exports in the first four years, but it was surpassed by Belgium in 2008. In 2009, Singapore recovered, reaching fourth place, and, since then, it has kept growing steadily, while Belgian exports have remained constant, lower than Singapore's.
Table 2. Annual average growth (US\$) for the Top 10 sparkling wine exporters.

\begin{tabular}{lcccc}
\hline & 2004 & 2018 & Difference & $\begin{array}{c}\text { Annual } \\
\text { average } \\
\text { growth (\%) }\end{array}$ \\
\hline France & $2,313,905$ & $3,767,259$ & $1,453,354$ & 4.18 \\
Italy & 306,052 & $1,786,570$ & $1,480,518$ & 32.00 \\
Spain & 344,511 & 599,128 & 254,617 & 4.92 \\
Singapore & 134,019 & 387,163 & 253,144 & 12.59 \\
Germany & 43,356 & 146,955 & 103,599 & 15.92 \\
Netherlands & 21,666 & 97,948 & 76,282 & 23.47 \\
UK & 17,632 & 54,561 & 36,929 & 13.96 \\
USA & 13,629 & 52,712 & 39,083 & 19.11 \\
Belgium & 19,093 & 45,629 & 26,536 & 9.26 \\
Australia & 47,948 & 43,155 & $-4,793$ & -0.66 \\
\hline
\end{tabular}

Source: Our own calculations based on ITC data.

The Netherlands, the USA, the UK and Germany also presented high annual average growth. The Netherlands was outstanding, with an annual average growth of $23.47 \%$. On the other hand, Australia presented a decrease of almost $1 \%$ per year.

\subsection{Market share and concentration of imports}

As seen in Table 3, imports of sparkling wines are unconcentrated. The USA, the UK and Japan are the importers holding the three largest market shares. 
Table 3. Market share and the HHI for the imports of sparkling wine.

\begin{tabular}{|c|c|c|c|c|c|c|c|c|c|c|c|c|c|c|c|}
\hline & 2004 & 2005 & 2006 & 2007 & 2008 & 2009 & 2010 & 2011 & 2012 & 2013 & 2014 & 2015 & 2016 & 2017 & 2018 \\
\hline$\overline{\text { USA }}$ & 18.2 & 17.6 & 17 & 14.3 & 11.9 & 12.6 & 14.1 & 14.9 & 14.8 & 14.8 & 14.7 & 17.9 & 19.5 & 19.5 & 19.1 \\
\hline UK & 21.8 & 21.1 & 18.7 & 17.4 & 15.7 & 17.5 & 17 & 15.3 & 14.7 & 14.3 & 15.8 & 16.8 & 15.4 & 13.4 & 13 \\
\hline Japan & 7.7 & 6.7 & 8.2 & 7 & 7 & 6 & 7.2 & 6.8 & 8 & 7.1 & 7.4 & 7.8 & 8.4 & 8.5 & 8.7 \\
\hline Germany & 11.5 & 11.3 & 12.4 & 9.6 & 10.6 & 11.6 & 9.9 & 11 & 9.2 & 8.9 & 7.9 & 7.3 & 7.5 & 7.4 & 7.1 \\
\hline Singapore & 3.8 & 5.6 & 4.6 & 4.3 & 3.9 & 3.1 & 4 & 4.3 & 4.5 & 4.8 & 5.7 & 5.4 & 4.8 & 5.4 & 5.1 \\
\hline Belgium & 6.5 & 6.2 & 5.7 & 10.5 & 10.9 & 7.6 & 6.1 & 6 & 6.1 & 6.5 & 5.7 & 4.7 & 4.4 & 4.3 & 4.4 \\
\hline Australia & 1.7 & 1.9 & 2.1 & 2.3 & 2.5 & 2.5 & 3.1 & 2.9 & 3.4 & 3.3 & 3 & 3.3 & 3.1 & 3.3 & 3.1 \\
\hline Italy & 5.2 & 5.1 & 5.3 & 5.7 & 5.1 & 4.4 & 3.8 & 3.8 & 3 & 2.6 & 2.5 & 2.7 & 2.9 & 2.9 & 3 \\
\hline Switzerland & 4.2 & 3.7 & 3.5 & 3.3 & 3.3 & 4.1 & 3.8 & 3.7 & 3.6 & 3.5 & 3.3 & 3.3 & 3.2 & 3.1 & 3 \\
\hline Russia & 1.4 & 1.5 & 1.4 & 2.2 & 2.6 & 2.3 & 3.6 & 4 & 3.5 & 4.2 & 3.3 & 1.9 & 2 & 2.5 & 2.8 \\
\hline HHI & 1,218 & 1,159 & 1,077 & 962 & 867 & 883 & 868 & 854 & 815 & 793 & 813 & 925 & 948 & 899 & 873 \\
\hline
\end{tabular}

Source: Our own calculations based on ITC data.

Besides these, Singapore, Australia and the Russian Federation showed considerable growth.

The USA and the UK switched their positions over the years. The UK initially held a market share of 21.8 points while the USA held 18.2. Since 2015, the UK showed a reduction in market share, while the USA increased steadily.

Japan and Germany also showed fluctuations in their market shares. Japanese market shares fluctuated until 2013, when a period of slow continuous growth began, resulting from consumption habit changes. The people began to view wine as a daily drink, and became increasingly curious about higher quality wines (Corsi et al., 2013), which generated an increase in sparkling wine consumption, especially among women (Rod and Beal, 2014). Germany, despite presenting a constant fall, starting with 11.5 points in 2004 and experiencing fluctuations between 2006 and 2011, continued to be a strong importer, due to having sparkling wine as an occasional celebratory beverage (Dressler, 2018). According to Szolnoki and Hoffmann (2014), it was one of the few countries in the world that had very diversified structured distribution channels, offering a wide variety of purchase points for the German sparkling wine consumer.

Singapore, Australia, and the Russian Federation have experienced remarkable growth. Singapore's market share started at 3.8 points in 2004 and closed at the end of the analysis with 5.1 points. Australia started with 1.7 points and finished at 3.1. Notably, the Russian Federation doubled its market share, which went from 1.4 points in 2004 to 2.8 in 2018.

The results for $\mathrm{HHI}$, throughout the timeline analysed, revealed that the market structure remained unconcentrated. In 2004, the index was 1,218, and, in 2018, it was 873 , i.e., a total deconcentration of approximately $30 \%$.

\subsection{Market share and concentration of exports}

Unlike imports, sparkling wine exports were concentrated. Analysing Table 4, it can be seen that the three largest exporters were France, Italy and Spain, totalling about $83 \%$ of the sparkling wine exportation in 2018. It is also noted that Singapore, Germany, the Netherlands, the USA and Australia showed significant changes.

France was the largest exporter of sparkling wine and remained stable in first place throughout the entire period. Its market share was the only one that exceeded the average of 50 points, confirming its greater capacity to create added value in international markets, a fact also identified in Lombardi et al. (2016).

With an emphasis on the evolution of the Italian sparkling wine market shares, it can be noted that they almost tripled, starting at 9.1 points and ending at 24.4 in 2018. The results show that, although the Italy figure grew, France underwent a significant decrease. Thus, it means that Italy increased its market share substantially based on France's decrease. Other countries, like Spain, had a lower increase or decrease in exportation.

The HHI for exports showed an equal decrease in imports, reducing by about $30 \%$. In 2004, it was 4,930 and in 2018 it was 3,342, indicating that, despite the reduction in its concentration, the sparkling wine export market remained highly concentrated.

\subsection{Relative position in the market}

Table 5 contains the RPM (Lafay et al., 1999) calculations for the 10 largest world exporters of sparkling wine. Analysing Table 5, it is possible to identify two players that held significant market positions, above 10 points, as follows: 
Table 4. Market participation and the HHI for the exports of sparkling wine.

\begin{tabular}{|c|c|c|c|c|c|c|c|c|c|c|c|c|c|c|c|}
\hline & 2004 & 2005 & 2006 & 2007 & 2008 & 2009 & 2010 & 2011 & 2012 & 2013 & 2014 & 2015 & 2016 & 2017 & 2018 \\
\hline France & 68.7 & 67.4 & 68.4 & 63.6 & 59.3 & 58.5 & 60.4 & 58.1 & 54.7 & 55.3 & 55.6 & 56.9 & 53.8 & 53.5 & 51.4 \\
\hline Italy & 9.1 & 9.1 & 9.3 & 10.2 & 11.4 & 13 & 12.6 & 13.7 & 14 & 16.6 & 17.9 & 18.9 & 22.3 & 23.1 & 24.4 \\
\hline Spain & 10.2 & 9.9 & 8.4 & 9.2 & 10.9 & 11.3 & 10.4 & 9.8 & 12.1 & 9.6 & 8.7 & 8.4 & 7.9 & 7.8 & 8.2 \\
\hline Singapore & 3.9 & 4 & 4.7 & 4.6 & 4 & 3.4 & 4.4 & 4.8 & 6 & 5.6 & 5.6 & 5.8 & 5.8 & 5.6 & 5.3 \\
\hline Germany & 1.3 & 1.7 & 1.9 & 1.9 & 2 & 3 & 2.8 & 2.8 & 2.6 & 2.5 & 2.3 & 1.9 & 2.1 & 2 & 2 \\
\hline Netherlands & 0.6 & 0.9 & 1 & 0.7 & 0.7 & 0.7 & 0.9 & 1.1 & 1.1 & 1 & 1 & 0.8 & 0.9 & 0.9 & 1.3 \\
\hline UK & 0.5 & 0.6 & 0.7 & 0.6 & 0.6 & 0.8 & 0.6 & 1.4 & 0.7 & 0.7 & 0.6 & 0.7 & 0.6 & 0.6 & 0.7 \\
\hline USA & 0.4 & 0.4 & 0.3 & 0.4 & 0.4 & 0.7 & 0.6 & 0.7 & 0.7 & 0.8 & 0.6 & 0.6 & 0.6 & 0.6 & 0.7 \\
\hline Belgium & 0.6 & 0.8 & 0.5 & 4 & 5 & 2.3 & 0.5 & 0.7 & 0.6 & 0.6 & 0.6 & 0.5 & 0.5 & 0.5 & 0.6 \\
\hline Australia & 1.4 & 1.6 & 1.7 & 1.4 & 1.2 & 1.4 & 1.5 & 1.4 & 1.3 & 1.1 & 0.9 & 0.8 & 0.8 & 0.7 & 0.6 \\
\hline HHI & 4,930 & 4,753 & 4,869 & 4,282 & 3,813 & 3,754 & 3,947 & 3,695 & 3,385 & 3,468 & 3,531 & 3,708 & 3,499 & 3,500 & 3,342 \\
\hline
\end{tabular}

Source: Our own calculations based on ITC data.

Table 5. Relative position in the market, 2004-2018.

\begin{tabular}{lccccccccccccccc}
\hline & 2004 & 2005 & 2006 & 2007 & 2008 & 2009 & 2010 & 2011 & 2012 & 2013 & 2014 & 2015 & 2016 & 2017 & 2018 \\
\hline France & 34.84 & 33.42 & 33.91 & 31.82 & 29.79 & 28.31 & 29.97 & 28.9 & 27.65 & 27.49 & 27.26 & 28.18 & 26.6 & 26.3 & 25.39 \\
Italy & 2.17 & 2.04 & 2.06 & 2.34 & 3.35 & 4.33 & 4.49 & 5.07 & 5.73 & 7.11 & 7.61 & 8.22 & 9.86 & 10.31 & 10.92 \\
Spain & 4.55 & 4.06 & 3.23 & 2.87 & 3.67 & 4.55 & 4.3 & 4.07 & 5.5 & 4.17 & 3.57 & 3.35 & 3.18 & 3.13 & 3.28 \\
Singapore & 0.2 & -0.73 & 0.08 & 0.21 & 0.16 & 0.13 & 0.21 & 0.29 & 0.92 & 0.44 & -0.05 & 0.26 & 0.57 & 0.18 & 0.16 \\
Germany & -4.91 & -4.74 & -5.22 & -3.77 & -4.25 & -4.3 & -3.44 & -4.07 & -3.13 & -3.1 & -2.83 & -2.65 & -2.64 & -2.62 & -2.42 \\
Netherlands & -0.56 & -0.04 & -0.66 & -0.87 & -0.85 & -0.76 & -0.56 & -0.56 & -0.45 & -0.39 & -0.5 & -0.43 & -0.35 & -0.32 & -0.22 \\
UK & -10.3 & -10.19 & -8.92 & -8.27 & -7.35 & -8.28 & -8.1 & -6.82 & -6.8 & -6.71 & -7.66 & -7.95 & -7.33 & -6.26 & -5.99 \\
USA & -8.64 & -8.53 & -8.29 & -6.85 & -5.59 & -5.94 & -6.68 & -7.01 & -6.81 & -6.92 & -7.08 & -8.53 & -9.3 & -9.26 & -9 \\
Belgium & -2.85 & -2.67 & -2.57 & -3.16 & -2.79 & -2.62 & -2.75 & -2.57 & -2.64 & -2.9 & -2.56 & -2.06 & -1.87 & -1.86 & -1.82 \\
Australia & -0.09 & -0.11 & -0.18 & -0.42 & -0.6 & -0.53 & -0.76 & -0.73 & -0.96 & -1.08 & -1.08 & -1.22 & -1.45 & -1.3 & -1.23 \\
\hline
\end{tabular}

Source: Our own calculations based on ITC data.

- France: from the analysis, it is possible to observe a fall of 9.45 points in French RPM. The highest mark was in the first year (2004) with 34.84 points, and, since then, the French figures have been decreasing continuously.

- Italy: showed steady growth, starting the analysis with 2.17 points and ending with 10.92. It had the biggest observed growth among the 10 largest exporters.

Despite having experienced periods of instability, Spain sometimes surpassed Italy's marks, and, because of its lower level of specialisation (see Mariani et al., 2012), it did not follow the Italian growth, remaining in the third-largest relative market position.

\subsection{Revealed Comparative Advantage}

Table 6 presents the RCA (Vollrath 1991) for the 10 largest world exporters of sparkling wine. France had the highest values for the revealed comparative advantage, starting at 15.11 points, and, despite fluctuations, it showed a slight growth over the years, ending at 17.43 points.

Italy showed the largest increase in its revealed comparative advantage. At the beginning of the analysis, it presented 2.33 points and, over the years, it showed continuous growth, without fluctuations, ending at 8.64 points. Thus, Italy tripled its revealed comparative advantage from 2004 to 2018 .

Spain started the analysis with marks higher than those of Italy, but, throughout the years, however, Italian values underwent continuous growth. Spain did not have the same flow, thus, since 2013, Italy remained con- 
Table 6. Revealed Comparative Advantage, 2004-2018.

\begin{tabular}{lccccccccccccccc}
\hline & 2004 & 2005 & 2006 & 2007 & 2008 & 2009 & 2010 & 2011 & 2012 & 2013 & 2014 & 2015 & 2016 & 2017 & 2018 \\
\hline France & 15.11 & 16.05 & 17.07 & 16.31 & 15.92 & 15.57 & 17.81 & 17.95 & 18.02 & 18.3 & 18.6 & 18.9 & 17.5 & 17.8 & 17.4 \\
Italy & 2.33 & 2.52 & 2.67 & 2.8 & 3.37 & 3.95 & 4.27 & 4.74 & 5.13 & 6.06 & 6.38 & 6.79 & 7.12 & 8.05 & 8.64 \\
Spain & 5.09 & 5.3 & 4.9 & 5.2 & 6.21 & 6.23 & 6.36 & 5.95 & 7.75 & 5.83 & 5.17 & 4.96 & 4.51 & 4.29 & 4.78 \\
Singapore & 1.82 & 1.81 & 2.04 & 2.12 & 1.89 & 1.53 & 1.87 & 2.07 & 2.66 & 2.49 & 2.56 & 2.66 & 2.74 & 2.61 & 2.47 \\
Germany & 0.12 & 1.81 & 0.19 & 0.19 & 0.2 & 0.03 & 0.03 & 0.03 & 0.34 & 0.32 & 0.12 & 0.23 & 0.25 & 0.24 & 0.25 \\
Netherlands & 0.18 & 0.25 & 0.29 & 0.19 & 0.2 & 0.2 & 0.26 & 0.38 & 0.36 & 0.33 & 0.34 & 0.31 & 0.33 & 0.31 & 0.44 \\
UK & 0.13 & 0.15 & 0.18 & 0.17 & 0.19 & 0.27 & 0.21 & 0.49 & 0.26 & 0.24 & 0.2 & 0.23 & 0.21 & 0.24 & 0.29 \\
USA & 0.04 & 0.04 & 0.03 & 0.04 & 0.04 & 0.07 & 0.07 & 0.08 & 0.08 & 0.09 & 0.07 & 0.06 & 0.06 & 0.06 & 0.08 \\
Belgium & 0.16 & 0.24 & 0.15 & 1.27 & 1.68 & 0.77 & 0.19 & 0.27 & 0.25 & 0.21 & 0.24 & 0.2 & 0.21 & 0.2 & 0.25 \\
Australia & 1.49 & 1.57 & 1.69 & 1.34 & 1.02 & 1.14 & 1.07 & 0.95 & 0.9 & 0.81 & 0.65 & 0.71 & 0.65 & 0.5 & 0.44 \\
\hline
\end{tabular}

Source: Our own calculations based on ITC data.

Table 7. Net Export Index for the main sparkling wine exporters.

\begin{tabular}{lccccccccccccccc}
\hline & 2004 & 2005 & 2006 & 2007 & 2008 & 2009 & 2010 & 2011 & 2012 & 2013 & 2014 & 2015 & 2016 & 2017 & 2018 \\
\hline France & 0.96 & 0.96 & 0.97 & 0.96 & 0.96 & 0.92 & 0.96 & 0.96 & 0.96 & 0.96 & 0.95 & 0.95 & 0.94 & 0.94 & 0.94 \\
Italy & 0.3 & 0.28 & 0.28 & 0.29 & 0.4 & 0.49 & 0.54 & 0.57 & 0.66 & 0.73 & 0.74 & 0.75 & 0.77 & 0.78 & 0.78 \\
Spain & 0.76 & 0.69 & 0.62 & 0.44 & 0.49 & 0.67 & 0.69 & 0.69 & 0.79 & 0.75 & 0.69 & 0.65 & 0.64 & 0.64 & 0.65 \\
Singapore & 0.05 & -0.15 & 0.01 & 0.04 & 0.04 & 0.04 & 0.05 & 0.06 & 0.17 & 0.08 & -0.01 & 0.04 & 0.1 & 0.03 & 0.03 \\
Germany & -0.78 & -0.73 & -0.73 & -0.66 & -0.69 & -0.59 & -0.54 & -0.59 & -0.53 & -0.55 & -0.55 & -0.58 & -0.54 & -0.56 & -0.53 \\
Netherlands & -0.45 & -0.34 & -0.4 & -0.56 & -0.54 & -0.51 & -0.39 & -0.33 & -0.28 & -0.27 & -0.32 & -0.33 & -0.27 & -0.26 & -0.14 \\
UK & -0.95 & -0.94 & -0.92 & -0.93 & -0.92 & -0.91 & -0.93 & -0.82 & -0.9 & -0.9 & -0.93 & -0.92 & -0.92 & -0.9 & -0.88 \\
USA & -0.95 & -0.95 & -0.96 & -0.94 & -0.93 & -0.89 & -0.91 & -0.9 & -0.89 & -0.89 & -0.91 & -0.93 & -0.93 & -0.93 & -0.92 \\
Belgium & -0.83 & -0.76 & -0.83 & -0.43 & -0.35 & -0.52 & -0.83 & -0.77 & -0.8 & -0.83 & -0.8 & -0.8 & -0.77 & -0.78 & -0.74 \\
Australia & -0.06 & -0.06 & -0.09 & -0.23 & -0.32 & -0.27 & -0.33 & -0.33 & -0.41 & -0.49 & -0.55 & -0.59 & -0.59 & -0.65 & -0.67 \\
\hline
\end{tabular}

Source: Our own calculations based on ITC data.

stant above the mark of 6 points, while Spain dropped from 5.09 points in 2004 to 4.78 in 2018.

Singapore's growth was relatively stable during the course of time. It is noticed, however, that, in 2005 and 2009, the country had its biggest falls, below the initial mark of 1.82 points. The highest mark was registered in 2017 at 2.74 points. On the other hand, Australia showed different behaviour from other significant countries. Despite starting in a position similar to Singapore, with 1.49 points, and showing growth in 2005 and 2006, it started, in 2007, to undergo a period of instability and decline, as it increased its sales volume to the detriment of quality (Corsi et al., 2013), ending with 0.44 points in 2018.

\subsection{Net Export Index}

The Net Export Index - NEI allows a better understanding of the commercial characteristics of the nations under this sparkling wine analysis. The NEI fluctuates between -1 (where the nation only imports the product) and 1 (where the nation only exports the product). When the index reaches 0 , the nation both imports and exports the product (Banterle and Carraresi, 2007). Table 7 contains the NEI values for the main sparkling wine exporters.

The results presented in Table 7 reveal that some countries' positions as producers or consumers were well established. However, the results also confirm Mariani et al. (2012) and Pomarici (2016), which shows that reexportation is a common action in the sparkling wine sector, specifically:

- France: Strong tendency to export. Features: fluctuates between its lowest mark, 0.92 points, and its highest mark, 0.97; the results indicated France as the world's largest exporter of sparkling wines.

Italy: Shows growth in exporting, registering an overall increase of 0.48 points. The lowest registered marks were in 2005 and 2006, at 0.28 points. Since 
2007, Italian marks show steady growth.

- Spain: Its net export index presented a stable line in export score.

- USA: Stable and consistent importer, the lowest marks were registered in 2009, 2012 and 2013 at -0.89 , and the highest mark registered was -0.96 in 2006.

- UK: Like the USA, the UK is a stable consistent importer, fluctuating between -0.95 and -0.82 .

- Singapore: Shows small fluctuation. The biggest imports mark was registered in 2005 at -0.15 points, and, in terms of exports, it was registered in 2012 at 0.17 points. Due to the proximity to the mark of 0 , it can be inferred that Singapore was a re-exporter. As an important transportation hub, sparkling wines from the main producing countries passed through Singapore before heading to southwest Asia and Japan (Rod and Beal, 2014).

- Australia: The country's figures showed that, in the first year of the analysis, it was classified as a reexporter. However, during the period, it is noted that the Australian NEI moved from 0 to -1. In 2018, the Australian NEI was -0.67 , classifying Australia as a sparkling wine importer. Despite being a large importer, mainly of French Champagne (Culbert et al., 2016), Australia presented a continuous contraction of its commercial specialisation (Galati et al., 2017). Domestic sales of Australian sparkling wine fell due to increased international competition and unfavourable exchange rates. Thus, it was concluded there was an increase in the volume of imported wine (Fleming et al., 2014; Verdonk et al., 2017).

\section{CONCLUSIONS}

This paper analysed the sparkling wine industry in terms of its competitiveness and international market structure. France was the largest exporter of sparkling wines in the world. The marks of its main competitors (Italy and Spain, respectively $23.1 \%$ and $7.8 \%$ of the market share in 2018) were far lower than those of France (51.4\% of the market share in 2018). On the other hand, the USA (19.5\% of the market share in 2018) and the UK (13.4\% of the market share in 2018) were the principal importers.

Regarding the HHI, the all the results are lower than 1,500 , revealing that the sparkling wine import market was unconcentrated. Thus, when comparing the number of competitors that have the largest market shares, it can be said that the sparkling wine import market was more balanced than the export market. The HHI for exports showed that it remained a very concentrated market, despite the general drop of 1,588 points in its concentration. It could be inferred that the sparkling wine export market consisted of a highly concentrated market, and that the largest share of this concentration lay in a single main competitor. While for exports France had the largest share, for imports we could observe four main importers: the USA, the UK, Japan, and Singapore.

The RCA showed that the countries with the greatest comparative advantage in the international sparkling wine market were: France (17.4), Italy (8.64) and Spain (4.78), and the relative market position reveals that these were the most significant countries in the international sparkling market, which Benoît et al. (2019) called the Old World wine market.

The NEI revealed, among leading exporters, three groups of actors who are: i) stable in terms of exports based on domestic production (France, Italy and Spain) with general number above 0.5 ; ii) stable in trade, reflecting re-export (Singapore and the Netherlands) with general numbers between -0.4 and 0.1 ; iii) stable in imports, with strong domestic consumption (Germany, the UK, the USA, Australia, and Belgium) with general numbers below -0.5 .

Trade based measures of competitiveness provide a realistic indicator of underlying competitiveness, but are a limitation for the period analysed, in this case 2004 to 2018. For future studies, two main goals are suggested regarding: i) the reasons why the comparative advantages in sparkling wine are changing in France and Italy, ii) the relation between old and new countries in the sparkling wine markets. For instance, does the New World sustain the Old World, and if so, why?

\section{REFERENCES}

Anderson, K. (2018). Australian wine industry competitiveness: why so slow to emerge?. Australian Journal of Agricultural and Resource Economics, 62(4), 507526.

Bain J., 1951. Relation of profit rate to industry concentration: American manufacturing, 1936-1940. Quarterly Journal of Economics 65, 293-324.

Balassa, B., 1965 Trade liberalization and 'revealed' comparative advantage. The Manchester School of Economic and Social Studies 33 (2), 99-123.

Balogh, J. M., Jámbor A. (2017) The global competitiveness of European wine producers, British Food Journal, 119:(9), pp. 2076-2088.

Banterle, A., Carraresi, L., 2007 Competitive performance analysis and European Union trade: The case of the 
prepared swine meat sector. Acta Agriculturae Scand Section C 4(3), 159-172.

Basso, M., 2019. Land-use changes triggered by the expansion of wine-growing areas: A study on the Municipalities in the Prosecco's production zone (Italy). Land Use Policy 83, 390-402.

Beluhova-Uzunova R., and Roycheva A. (2017) Competitive advantages of the Bulgarian viticulture and wine sector after the accession to the European Union. Trakia Journal of Sciences, Vol. 15, Suppl. 1, pp 324-329

Benoît, L., William, A., Lindsey, H., Adrienne, L. F., Marianne, M. W., 2019. Wine sector: Definitions and nuances from global to country analysis - A comparison between Old World, New World, and emerging wine countries from 2005 to current. In Santini, C. Cavicchi, A. (eds.) Case Studies in the Wine Industry (pp. 7-32). Woodhead Publishing.

Bojnec S., Fertö I., 2009. Agro-food trade competitiveness of Central European and Balkan countries. Food Policy 34, 417-425.

Castellini, A., Samoggia, A., 2018. Millennial consumers' wine consumption and purchasing habits and attitude towards wine innovation. Wine Economics and Policy 7(2), 128-139.

Correia, L., Gouveia, S., Martins, P., 2019. The European wine export cycle. Wine Economics and Policy 8(1), 91-101.

Corsi, A. M., Marinelli, N., Sottini, V. A., 2013. Italian wines and Asia: policy scenarios and competitive dynamics. British Food Journal 115(3), 342-364.

Crescimanno, M., Galati, A., 2014. Competitiveness of Italian wines in the international market. Bulgarian Journal of Agricultural Science 20(1), 12-22.

Culbert, J., Verdonk, N., Ristic, R., Olarte Mantilla, S., Lane, M., Pearce, K., Cozzolino, D., Wilkinson, K., 2016. Understanding consumer preferences for Australian sparkling wine vs. French Champagne. Beverages 2(3), 1-19.

Demossier, M., 2011. Beyond terroir: territorial construction, hegemonic discourses, and French wine culture. Journal of the Royal Anthropological Institute 17(4), 685-705.

Drescher, K., Maurer, O., 1999. Competitiveness in the European dairy industries. Agribusiness: An International Journal 15(2), 163-177.

Dressler, M., 2018. The German wine market: a comprehensive strategic and economic analysis. Beverages 4(4), 92.

Epstein, B. S., 2011. Champagne: a global history. Reaktion Books.

Fleming, E., Mounter, S., Grant, B., Griffith, G., Villano, R., 2014. The New World challenge: Performance trends in wine production in major wine-exporting countries in the 2000s and their implications for the Australian wine industry. Wine Economics and Policy $3(2), 115-126$.

Galati, A., Tinervia, S., Crescimanno, M., Spezia, F., 2017. Changes in the international wine market competitiveness. International Journal of Globalisation and Small Business 9(4), 277-293.

Hannin, H., Couderc, J. P., Hauteville, F., Montaigne, E., 2010. La vigne et le vin: mutations économiques en France et dans le monde. La documentation Francaise, Paris.

Horn, E. J., 1985. Internationale Wettbewerbsfähigkeit von Ländern. WiST-Wirtschaftswissenschaftliche Studien 7, 323-329.

INTERNATIONAL TRADE CENTER - ITC. Market analysis and research. Available in: http://legacy. intracen.org/marketanalysis/Default.aspx. January 27, 2020.

Iwasaki, N., Seldon, B. J., Tremblay, V. J., 2008. Brewing wars of attrition for profit (and concentration). Review of Industrial Organization 33(4), 263-279.

Lafay, G., 1999. Nations et mondialisation. Paris: Economica.

Latruffe, L., 2010. Competitiveness, productivity and efficiency in the agricultural and agri-food sectors. OECD Food, Agri culture and Fisheries Papers 30, 417-449.

Lerro, M., Vecchio, R., Nazzaro, C., Pomarici, E., 2020. The growing (good) bubbles: insights into US consumers of sparkling wine. British Food Journal 122 (8), 2371-2384.

Lombardi, P., Dal Bianco, A., Freda, R., Caracciolo, F., Cembalo, L., 2016. Development and trade competitiveness of the European wine sector: A gravity analysis of intra-EU flows. Wine Economics and Policy 5(1), 50-59.

Mariani, A., Pomarici, E., Boatto, V., 2012. The international wine trade: Recent trends and critical issues. Wine Economics and Policy 1(1), 24-40.

Pascucci, F., 2018. The export competitiveness of Italian coffee roasting industry. British Food Journal 120(7), $1529-1546$.

Phillips, R., 2016. French wine: A history. Univ of California Press.

Pomarici, E., 2016. Recent trends in the international wine market and arising research questions. Wine Economics and Policy 5 (1), 1-3.

Rod, M., Beal, T., 2014. The experience of New Zealand in the evolving wine markets of Japan and Singapore. Asia-Pacific Journal of Business Administration 6(1), 49-63. 
Rokka, J., 2017. Champagne: marketplace icon. Consumption Markets and Culture 20(3), 275-283.

Rossetto, L., Gastaldello, G., 2018. The Loyalty Structure of Sparkling Wine Brands in Italy. Journal of Wine Economics 13(4), 409-418.

Scherer, F. M., Ross, D., 1990. Industrial market structure and economic performance. (2 ed.). Boston: Houghton-Mifflin..

Stevenson, T., 2003. World Encyclopedia of Champagne and Sparkling Wine. Wine Appreciation Guild.

Szolnoki, G., Hoffmann, D., 2014. Consumer segmentation based on usage of sales channels in the German wine market. International Journal of Wine Business Research 26(1), 27-44.

Thomé, K. M., Soares, A. D. B. P., 2015. International market structure and competitiveness at the malted beer: from 2003 to 2012. Agricultural Economics 61(4), 166-178.

Thomé, K. M., Medeiros, J. J., 2016. Drivers of successful international business strategy: insights from the evolution of a trading company. International Journal of Emerging Markets 11(1), 89-110.

Thomé, K. M., Medeiros, J. J., Hearn, B. A., 2017. Institutional distance and the performance of foreign subsidiaries in Brazilian host market. International Journal of Emerging Markets 12(2), 279-295.

U. S. Department of Justice and Federal Trade Commission, Horizontal Merger Guidelines; 2010. Accessed 20 December 2019. Available: https://www.justice. gov/sites/default/files/atr/legacy/2010/08/19/hmg2010.pdf

Van Rooyen, J., Stroebel, L., \& Esterhuizen, D. (2010, January). Analysing competitiveness performance in the wine industry: the South African case. In AARES conference (pp. 7-9).

Velikova, N., Charters, S., Fountain, J., Ritchie, C., Fish, N., Dodd, T., 2016. Status or fun? A crosscultural examination of young consumers' responses to images of champagne and sparkling wine. British Food Journal 118(8), 1960-1975.

Verdonk, N., Wilkinson, J., Culbert, J., Ristic, R., Pearce, K., Wilkinson, K., 2017. Toward a model of sparkling wine purchasing preferences. International Journal of Wine Business Research 29(1), 58-73.

Vollrath T. L., 1991. A theoretical evaluation of alternative trade intensity measures of revealed comparative advantage. WeltwirtschaftlichesArchiv 130, 265-279.

Zhao, W., 2005. Understanding classifications: Empirical evidence from the American and French wine industries. Poetics 33(3-4), 179-200. 